\title{
Disfungsi Peraturan Perundang-Undangan Tanggung Jawab Sosial dan Lingkungan di Indonesia
}

\author{
Lego Karjoko, Josephine Santosa, dan I Gusti Ayu Ketut Rachmi Handayani \\ Fakultas Hukum Universitas Sebelas Maret Surakarta \\ Jln. Ir. Sutami 36 A, Kentingan - Surakarta \\ legokarjoko@staff.uns.ac.id; josephine.santosa@live.com; dan ayu_igk@yahoo.com;
}

Received: 10 Januari 2019; Accepted: 22 April 2019; Published: 22 Agustus 2019

DOI: 10.20885/iustum.vol26.iss2.art5

\begin{abstract}
This study is aimed to analyse various Indonesian national regulations that govern about the implementation of social and environmental responsibility (SER) in the actualisation of its objectives for the equitable distribution of natural resources in Indonesia. The analysis is undertaken in terms of the phrases used, the subjects who are obliged to perform SER, the funding sources, the allocation of the funds, the instructed programs, as well as the course of the SER itself. By using normative legal research, this study concludes that the existing regulations have not consistently governed the implementation and standards of SER as expected by the Government. Additionally, according to Fuller, this kind of multi-interpretation will result in the malfunction of legal products, and ultimately frustrate the achievement of the SER objectives. On this matter, it is proposed that the Indonesian government needs to formulate a regulation that comprehensively and specifically govern about the SER to become a guideline for all the existing stakeholders.
\end{abstract}

Keywords: Dysfunctional regulations; equitable distribution of benefits; social and environmental responsibility

Abstrak

Penelitian ini menganalisis berbagai peraturan di Indonesia yang mengatur implementasi tanggung jawab sosial dan lingkungan (TJSL) di Indonesia dalam mewujudkan tujuan TJSL untuk pemerataan sumber daya alam. Kajian tersebut dilihat dari sisi penggunaan frasa, subjek yang berkewajiban melaksanakan TJSL, sumber dana, alokasi dana, program yang diinstruksikan, serta orientasi dari pengaturan TJSL itu sendiri. Dengan menggunakan penelitian hukum normatif, maka penelitian ini menyimpulkan bahwa peraturan-peraturan yang ada belum secara konsisten mengatur pelaksanaan dan standar TJSL yang diharapkan oleh negara ataupun pemerintah. Selain itu, menurut Fuller, multitafisir seperti ini akan mengakibatkan tidak berfungsinya produk hukum, dan pada akhirnya menggagalkan pencapaian tujuan TJSL itu sendiri. Atas hal ini, maka diusulkan bahwa pemerintah Indonesia perlu membuat satu peraturan yang secara komprehensif dan khusus mengatur mengenai TJSL agar dapat menjadi pedoman bagi seluruh pemangku kepentingan yang ada.

Kata-kata Kunci: Tanggung jawab sosial dan lingkungan; disfungsi peraturan; pemerataan manfaat 


\section{Pendahuluan}

Tuntutan perkembangan industri tidak bisa terlepas dengan sifat eksploitasi terhadap tenaga kerja maupun pemanfaatan sumber daya alam. ${ }^{1}$ Apabila dilakukan terus menerus, maka hal ini akan memunculkan konflik antara industri dengan tenaga kerja, ${ }^{2}$ maupun masyarakat dan lingkungan sekitarnya. ${ }^{3}$ Konsep Corporate Social Responsibility (CSR) atau Tanggung Jawab Sosial dan Lingkungan (TJSL) hadir untuk mencegah potensi konflik tersebut melalui berbagai cara untuk meminimalkan atau bahkan menghilangkan efek berbahaya yang mungkin timbul. ${ }^{4}$ TJSL berusaha memberikan 'ruh' kemanusiaan kepada perusahaan yang bersifat individualistik dengan menggeser paradigma awal di mana tujuan bisnis hanyalah untuk mengejar keuntungan (profit) agar lebih memperhatikan lingkungan (planet) dan kesejahteraan masyarakat (people). ${ }^{5}$ TJSL merupakan respon perusahaan untuk melakukan suatu proses peningkatan kualitas kehidupan masyarakat melalui pemberian pelayanan maupun tunjangan sosial, sesuai dengan harapan di mana pembangunan ekonomi nasional harus diselenggarakan berdasarkan demokrasi ekonomi yang berprinsip kebersamaan, efisiensi berkeadilan, berkelanjutan, berwawasan lingkungan, dan kemandirian serta untuk mewujudkan peningkatan kesejahteraan masyarakat. ${ }^{6}$ Ia juga merupakan instrumen Pasal 33 Undang-Undang Dasar Negara Republik Indonesia 1945 untuk membantu mencapai pemerataan manfaat seluas-luasnya kepada masyarakat, tidak sekedar dikuasai oleh segelintir orang. Atas manfaat yang dapat diberikan, maka penerapan dan pengaturan TJSL menjadi penting agar subjek hukum yang ada dapat menjadi kepanjangan tangan pemerintah untuk mewujudkan tujuan tersebut.

\footnotetext{
$30-31$.

${ }^{1}$ E. F. Schumacher, Small is Beautiful: Economics As If People Mattered, Harper \& Row, New York, 1973, hlm.

2 Totok Mardikanto, CSR (Corporate Social Responsibility) (Tanggungjawab Sosial Korporasi), Alfabeta, Bandung, 2014, hlm. 83.

${ }^{3}$ Otto Soemarwoto, Dampak Lingkungan dan Masyarakat, Gadjah Mada University Press, Yogyakarta, 2000, hlm. 29.

${ }^{4}$ Lois A. Mohr, Deborah, J. Webb, dan Katherine E. Harris, "Do Consumers Expect Companies to Be Socially Responsible? The Impacts of Corporate Social Responsibility on Buying Behavior", Journal of Consumer Affairs Vol. 35 No. 1, 2001, hlm. 47.

${ }^{5}$ John Elkington, Cannibals with Forks: The Triple Bottom Line of 21 $1^{\text {st }}$ Century Business, Capstone, Minnesota, 1999, hlm. 7.

${ }^{6}$ Samuel R. Adinugroho, Budiharto, Joko Priyono, "Pelaksanaan Tanggung Jawab Sosial Dan Lingkungan PT. Pertamina Semarang (Persero) Ditinjau Dari Undang-Undang Nomor 40 Tahun 2007 tentang Perseroan Terbatas", Diponegoro Law Journal Vol. 6 No. 1, 2007, hlm. 2.
} 
Secara yuridis, implementasi pengaturan TJSL di Indonesia dimulai melalui Undang-Undang Nomor 25 Tahun 2007 tentang Penanaman Modal yang menyebutkan bahwa setiap penanam modal memiliki kewajiban untuk melaksanakan tanggung jawab sosial. Konsep ini berlaku untuk berbagai bentuk perusahaan dan usaha, seperti perseroan terbatas, perusahaan yang bergerak di bidang minyak dan gas bumi, pertambangan mineral dan batubara, serta BUMN. Regulasi untuk bentuk-bentuk perusahaan tersebut memainkan peran penting dalam melembagakan TJSL di Indonesia melalui instruksi pelaksanaan TJSL baik secara eksplisit maupun implisit. Artinya proses ini mengubah sifat TJSL yang bersifat etis, moral, dan sukarela menjadi suatu norma yang menimbulkan kewajiban dan sanksi. ${ }^{7}$

Indonesia belum memiliki peraturan yang baku mengenai hal tersebut. Sehingga menimbulkan pelaksanaan yang masih bervariasi antar-perusahaan. Sebagai contoh adalah pengimplementasian Program Kemitraan dan Bina Lingkungan pada PT Pertamina (Persero) yang juga dibarengi dengan pelaksanaan program CSR. ${ }^{8}$ Kegiatan CSR ditujukan untuk memberikan kontribusi kepada masyarakat di bidang pendidikan, kesehatan, infrastruktur dan lingkungan hidup. CSR dilaksanakan untuk mendukung kegiatan operasi Pertamina dan perolehan proper dari berbagai unit operasi. Sedangkan kegiatan Bina Kemitraan dan Lingkungan dibagi ke dalam dua kegiatan, yaitu Bina Lingkungan dan Bina Kemitraan. Bina Lingkungan fokus pada bantuan pendidikan, bencana alam, pembangunan sarana ibadah, olahraga dan peningkatan kesehatan masyarakat. Bina Kemitraan terkait dengan pemberian modal usaha, pembinaan dan perluasan akses pasar bagi pengusaha kecil. ${ }^{9}$

Kedua program tersebut nampak memiliki tujuan yang sama. Namun, karena penggunaan istilah yang berbeda serta diatur dalam peraturan yang berbeda, maka menimbulkan tumpang tindih pelaksanaannya. Kedua kegiatan ini sama-sama mengeluarkan biaya, sehingga dapat dikatakan PT Pertamina (Persero)

\footnotetext{
${ }^{7}$ Patricia Rinwigati Waagstein, “The Mandatory Corporate Social Responsibility in Indonesia: Problems and Implications", Journal of Business Ethics Vol. 98, 2010, hlm. 465.

${ }^{8}$ Lihat Laporan Tahunan PT Pertamina (Persero) Tahun 2015.

${ }^{9}$ Lihat Laporan Tahunan PT Pertamina (Persero) Tahun 2018, hlm. 30
} 
mengeluarkan biaya yang berlipat pula. Bagi dunia usaha, ketidakjelasan ini menimbulkan risiko berupa pengeluaran biaya yang tentu akan mengurangi proyeksi laba. Apabila tidak ditangani dengan baik, maka hal ini akan menurunkan insentif bagi bidang usaha untuk melaksanakan kegiatan TJSL. Bahkan, terbuka penafsiran internal perusahaan dengan memilih program yang lebih menguntungkan dan sejalan dengan tujuan perusahaan. Sehingga, tujuan sejati TJSL tidak dapat tercapai. Dengan adanya penurunan kepatuhan, maka penyampaian manfaat dari perusahaan dari masyarakat juga akan berkurang, sehingga tujuan TJSL untuk mewujudkan pembagian manfaat yang lebih merata akan terhalang.

\section{Rumusan Masalah}

Berdasarkan latar belakang tersebut, maka penelitian ini berusaha menganalisis apakah berbagai peraturan mengenai TJSL telah disajikan secara jelas dan konsisten sehingga dapat menjadi suatu sistem hukum yang baik dalam pengaturan TJSL di Indonesia?

\section{Tujuan Penelitian}

Tujuan dari penelitian ini adalah untuk menganalisis berbagai peraturan mengenai TJSL telah disajikan secara jelas dan konsisten sehingga dapat menjadi suatu sistem hukum yang baik bagi pengaturan TJSL di Indonesia. Sehingga, dapat memberikan masukan-masukan yang dapat digunakan untuk konstruksi pengaturan TJSL di masa mendatang.

\section{Metode Penelitian}

Metode yang digunakan pada penelitian ini adalah metode penelitian doktrinal dengan pendekatan perundang-undangan dan pendekatan konsep. Penelitian ini menggunakan teknik analisis silogisme deduktif dan interpretasi terhadap berbagai bahan hukum primer berupa peraturan perundang-undangan, antara lain Undang-Undang Nomor 40 Tahun 2007 tentang Perseroan Terbatas, Undang-Undang Nomor 25 Tahun 2007 tentang Penanaman Modal, UndangUndang Nomor 22 Tahun 2001 tentang Minyak dan Gas Bumi, Undang-Undang Nomor 4 Tahun 2009 tentang Pertambangan Mineral dan Batubara, UndangUndang Nomor 32 Tahun 2009 tentang Perlindungan dan Pengelolaan Lingkungan 
Hidup, Undang-Undang Nomor 19 Tahun 2013 tentang Badan Usaha Milik Negara, dan Peraturan Menteri Badan Usaha Milik Negara Nomor PER02/MBU/07/ 2017 tentang Perubahan Kedua Atas Peraturan Menteri Badan Usaha Milik Negara Nomor PER-09/MBU/07/2015 tentang Program Kemitraan dan Program Bina Lingkungan Badan Usaha Milik Negara. Untuk mendukung bahan hukum primer, penelitian ini menggunakan bahan hukum sekunder berupa buku, jurnal, karya ilmiah yang sesuai. Bahan-bahan hukum tersebut dikumpulkan melalui studi pustaka.

\section{Hasil Penelitian dan Pembahasan}

Menurut teori Fuller, berfungsi atau tidaknya suatu sistem hukum diukur berdasarkan parameter moral internal sistem hukum itu sendiri. ${ }^{10}$ Prinsip tersebut terbagi menjadi 8,11 di antaranya termasuk kejelasan atau tidak multitafsir, dan tidak boleh saling bertentangan. Kata 'jelas' berarti rumusan yang disusun harus mudah dimengerti. Kata 'multitafsir' berasal dari kata 'multi' dan 'tafsir' atau 'interpretasi.' Menurut kamus Merriam-Webster, 'interpretasi' berarti hasil dari menginterpretasi atau menjelaskan sesuatu. Sehingga dalam konteks ini, kata 'tidak multitafsir' dapat diartikan bahwa peraturan perlu memberikan gambaran secara jelas, lugas, dan tidak memberikan banyak ruang untuk interpretasi sendiri menurut pembacanya. 'Tidak saling bertentangan' artinya peraturan saling koheren atau tidak kontradiktif. Ketika tidak ada konsistensi antara aturan yang satu dengan yang lain, maka hal ini akan membuka kesempatan bagi subjek hukum untuk menginterpretasikan aturan sesuai dengan kepentingannya atau orientasinya sendiri.

Berdasarkan teori tersebut, maka penelitian ini akan menelaah apakah peraturan-peraturan yang mengandung norma kewajiban TJSL telah dirancang dan disusun secara konsisten sehingga dapat menghasilkan suatu sistem hukum TJSL yang baik. Penafsiran ini akan dicapai melalui analisis dari prespektif (1) penggunaan frasa, (2) subjek, (3) sumber dana, (4) alokasi, dan (5) program.

\footnotetext{
${ }^{10}$ M.R. Zafer, Jurisprudence: An Outline, International Law Book Series, Kuala Lumpur, 1994, hlm. 45.

11 Delapan prinsip legalitas menurut Fuller adalah (1) bersifat umum, (2) dapat diakses publik atau harus diumumkan, (3) berorientasi ke masa depan atau tidak berlaku surut, (4) jelas, (5) konsisten dan tidak kontradiktif, (6) realistis untuk dilaksanakan, (7) konsisten untuk waktu yang relatif lama, dan (8) adanya kesesuaian antara peraturan tertulis dan pelaksanaan dari peraturan-peraturan tersebut. Lihat Colleen Murphy, "Lon Fuller and the Moral Value of the Rule of Law," Law and Philosophy Vol. 24, 2005, hlm. 240.
} 


\section{Undang-Undang Nomor 40 Tahun 2007 tentang Perseroan Terbatas}

Undang-Undang Perseroan Terbatas (UUPT) menggunakan kata "tanggung jawab sosial dan lingkungan" untuk mengacu kepada konsep CSR yang diakui secara internasional. Walaupun terjemahan langsung dari frasa tersebut adalah "corporate social and environmental responsibility" namun kata "social" dianggap telah mewakili lingkungan secara umum, sehingga istilah TJSL dapat dipersamakan dengan konsep CSR.12 Ayat ini menginstruksikan bahwa "Perseroan yang menjalankan kegiatan usahanya di bidang dan/atau berkaitan dengan sumber daya alam wajib melaksanakan Tanggung Jawab Sosial dan Lingkungan." Penggunaan istilah ini mengindikasikan bahwa TJSL merupakan bukan lagi sekedar tuntutan moral namun telah menjadi kewajiban perusahaan yang harus dilaksanakan. Apabila ditafsirkan secara autentik, maka kata "sumber daya alam" dapat mengacu pada segala kekayaan hayati dan non-hayati yang ada di alam dan lingkungan. Menurut penafsiran ini, hanya Perseroan yang bergerak di bidang sumber daya alam saja yang dikenai kewajiban TJSL. Perseroan yang dimaksud juga sebatas perseroan terbatas sesuai Undang-Undang Perseroan Terbatas, sehingga tidak mencakup bentuk-bentuk usaha lain seperti Koperasi, Yayasan, Perkumpulan, $\mathrm{CV}$, maupun bentuk bisnis lainnya.

Dana kegiatan TJSL perlu dianggarkan atau dialokasikan dan diperhitungkan sebagai biaya perusahaan. Alokasi dananya diserahkan kepada kepada Rapat Umum Pemegang Saham (RUPS) Perseroan tersebut dengan jumlah atau angka yang memperhatikan kepatutan dan kewajaran. Hal ini tentu membuka kesempatan untuk pengalokasian dana TJSL yang dibuat sesuai dengan tujuan perseroan. Karena latar belakang pendirian perseroan terbatas adalah untuk menciptakan laba sebesarbesarnya, ${ }^{13}$ maka wajar apabila manajemen menganggarkan dana TJSL seminimum mungkin untuk menekan biaya. Program yang perlu dilakukan juga tidak distandardisasi, sehingga perseroan dapat memilih kegiatan-kegiatan yang dinilai murah dan tetap mendukung maksimalisasi profit.

${ }^{12}$ Joseph DesJardins, 1998, “Corporate Environmental Responsibility,” Journal of Business Ethics 17(8), hlm.

13 Paddy Ireland, 2010, "Limited Liability, Shareholder Rights and the Problem of Corporate Irresponsibility," Cambridge Journal of Economics 34(5), hlm. 837. 


\section{Undang-Undang Nomor 25 Tahun 2007 tentang Penanaman Modal}

Menurut Undang-Undang Nomor 20 Tahun 2007 tentang Penanaman Modal (UUPM) frasa yang digunakan untuk menyebut konsep TJSL adalah "tanggung jawab sosial perusahaan" dan "menghormati tradisi budaya masyarakat" sebagaimana tercantum dalam ayat (b) dan ayat (d) pada Pasal 15 yang dalam kalimat lengkapnya berbunyi "setiap penanam modal berkewajiban: (b) melaksanakan tanggung jawab sosial perusahaan, (d) menghormati tradisi budaya masyarakat sekitar lokasi kegiatan usaha penanaman modal." Pasal 16 juga menggunakan frasa "menjaga kelestarian lingkungan hidup" sebagai bagian dari konsep TJSL.

Bentuk kegiatan yang diharapkan dari implementasi UUPM ini nampak dari frasa-frasa yang digunakan, yaitu menghormati tradisi budaya masyarakat maupun menjaga kelestarian lingkungan hidup, walaupun cara-cara konkretnya dikembalikan kepada masing-masing perusahaan. Kata “tanggung jawab sosial perusahaan" dapat diartikan sebagai tanggung jawab yang melekat pada setiap penanam modal untuk menciptakan hubungan yang serasi, seimbang, sesuai dengan lingkungan, nilai, norma, dan budaya masyarakat setempat. Peraturan ini tidak mengatur mengenai program dan kegiatan TJSL seperti apa yang perlu dilakukan, namun beberapa frasa sebelumnya memberikan gambaran yang lebih terarah apabila dibandingkan dengan instruksi dari UUPT. Subjek hukum yang dikenai peraturan ini adalah semua penanam modal. Bagi penanam modal yang secara khusus bergerak di sumber daya alam tidak terbarukan juga diberikan tambahan kewajiban untuk mengalokasikan dana untuk pemulihan lokasi yang memenuhi standar lingkungan hidup. Tentu hal ini bertujuan untuk mengantisipasi kerusakan lingkungan yang sangat mungkin disebabkan sebagai efek samping dari kegiatan para penanam modal.

\section{Undang-Undang Nomor 22 Tahun 2001 tentang Minyak dan Gas Bumi}

Undang-Undang Nomor 22 Tahun 2001 tentang Minyak dan Gas Bumi (UU Migas) tidak secara eksplisit menyebutkan bahwa perusahaan yang bergerak di bidang minyak dan gas wajib melakukan kegiatan TJSL. Namun kewajiban tersebut dicantumkan dalam pengaturan Kontrak Kerja yang mewajibkan 
perusahaan untuk memiliki komitmen dalam hal $(\mathrm{k})$ pengelolaan lingkugan hidup dan (p) pengembangan masyarakat sekitarnya dan jaminan hak-hak masyarakat. ${ }^{14}$

Berdasarkan perjanjian ini, maka perusahaan di kegiatan usaha hulu maupun di kegiatan usaha hilir ${ }^{15}$ memiliki kewajiban untuk turut bertanggung jawab dalam mengembangkan lingkungan dan masyarakat setempat. Komitmen tersebut juga harus dilaksanakan oleh Badan Usaha Milik Negara (BUMN), Badan Usaha Milik Daerah (BUMD), koperasi dan usaha kecil, serta badan usaha swasta. ${ }^{16}$ Peraturan ini tidak mengatur mengenai alokasi dana maupun sumber dana untuk kegiatankegiatan pelestarian lingkungan dan pemberdayaan masyarakat tersebut. Program kegiatan TJSL tidak diatur secara spesifik, namun subjek hukum dapat mengacu kepada Pasal 40 ayat (3) yang menerangkan bahwa pengelolaan lingkungan dapat diwujudkan dalam bentuk pencegahan dan penanggulangan pencemaran serta pemulihan atas terjadinya kerusakan pada lingkungan hidup, termasuk kewajiban pascaoperasi pertambangan.

\section{Undang-Undang Nomor 4 Tahun 2009 tentang Pertambangan Mineral dan Batubara}

Undang-Undang Pertambangan Mineral dan Batubara (UU Minerba) menginstruksikan pelaksanaan TJSL secara implisit melalui Pasal 108 ayat (1) yang menyebutkan bahwa pemegang Izin Usaha Pertambangan (IUP) dan Izin Usaha Pertambangan Khusus (IUPK) wajib menyusun program untuk pengembangan dan pemberdayaan masyarakat. Menurut Undang-Undang ini, konsep TJSL disebut sebagai "pemberdayaan masyarakat" yang dapat diartikan sebagai usaha untuk meningkatkan kemampuan masyarakat lokal secara individual ataupun kolektif agar tingkat kehidupannya menjadi lebih baik. ${ }^{17}$

Melalui penjelasan pada Pasal 6 ayat (1) Peraturan Pemerintah Nomor 23 Tahun 2010 tentang Pelaksanaan Kegiatan Usaha Pertambangan Mineral dan Batubara, diketahui bahwa subjek yang wajib melaksanakan kegiatan pemberdayaan masyarakat adalah badan usaha, koperasi, dan perseorangan yang mendapat IUP maupun IUPK. Walaupun regulasi ini tidak mengatur secara

\footnotetext{
14 Pasal 11 Undang-Undang Nomor 22 Tahun 2001 tentang Minyak dan Gas Bumi.

15 Ibid, Pasal 40 ayat (5).

${ }^{16}$ Ibid, Pasal 9 ayat (1).

${ }^{17}$ Pasal 1 ayat (28) Undang-Undang Nomor 4 Tahun 2009 tentang Pertambangan Mineral dan Batubara.
} 
spesifik mengenai jenis kegiatan ataupun program TJSL yang perlu dilakukan, namun usaha pemberdayaan masyarakat dapat mengacu kepada prinsip-prinsip saling menghargai, refleksi, perhatian, dan partisipasi sehingga mereka yang belum menerima manfaat bisa mendapat akses untuk menerima manfaat tersebut. ${ }^{18}$ Apapun bentuk program yang dicanangkan, perlu diprioritaskan untuk masyarakat yang berdomisili di sekitar area kerja WIUP dan WIUPK yang terkena dampak langsung dari aktifitas penambangan. Regulasi ini lebih mementingkan area secara geografis dibandingkan batas administrasi wilayah kecamatan ataupun kabupaten. Kegiatan pengembangan masyarakat juga harus memperhatikan kelestarian lingkungan, ${ }^{19}$ yang berarti pengusaha tambang harus melaksanakan kegiatan pascatambang yang berupa "kegiatan terencana, sistematis, dan berlanjut setelah akhir sebagian atau seluruh kegiatan usaha pertambangan untuk memulihkan fungsi lingkungan alam dan fungsi sosial menurut kondisi lokal di seluruh wilayah penambangan." 20

Walaupun besaran alokasi dana tidak ditentukan, namun program pengembangan dan pemberdayaan masyarakat ini wajib dianggarkan sebagai biaya program pengembangan dan pemberdayaan masyarkaat yang disiapkan setiap tahun sebagai bagian dari Rencana Kerja dan wajib disampaikan kepada pejabat terkait. ${ }^{21}$

\section{Undang-Undang Nomor 21 Tahun 2014 tentang Panas Bumi}

Panas bumi merupakan kekayaan alam yang dikuasai oleh negara dan dipergunakan seluas-luasnya untuk kemakmuran rakyat melalui kemandirian energi dan dukungan atas pembangunan yang berkelanjutan. Sebagai energi alternatif, panas bumi merupakan energi terbarukan yang ramah lingkungan dan berperan dalam mengurani emisi gas rumah kaca. Apabila dimanfaatkan secara optimum, panas bumi dapat memenuhi kebutuhan energi nasional. ${ }^{22}$ Walaupun dikuasai oleh negara, namun dalam pengelolaannya pemerintah pusat dapat

18 Douglas D. Perkins dan Marc A. Zimmerman, 1995, "Empowerment Theory, Research, and Application," American Journal of Community Psychology 23(5), hlm. 570.

${ }^{19}$ Pasal 8 ayat (1) Undang-Undang Nomor 4 Tahun 2009 tentang Pertambangan Mineral dan Batubara.

${ }^{20}$ Ibid, Pasal 1 ayat (27).

21 Pasal 106 dan 107 Peraturan Pemerintah Nomor 23 Tahun 2010 tentang Pelaksanaan Kegiatan Usaha Pertambangan Mineral dan Batubara.

22 Pasal 3 dan 4 Undang-Undang Nomor 21 Tahun 2014 tentang Panas Bumi. 
mendelegasikannya kepada para pelaku usaha yang disebut Pemegang Izin Panas Bumi dan dapat berbentuk BUMN, BUMD, koperasi, ataupun Perseroan Terbatas yang berkedudukan di Indonesia. ${ }^{23}$ Sehingga segala kewajiban termasuk kewajiban CSR terhadap lingkungan dan masyarakat juga menjadi tanggung jawab mereka.

Undang-Undang tentang Panas Bumi tidak menyebutkan sumber dana maupun alokasi yang diharapkan untuk kegiatan pengembangan dan pemberdayaan masyarakat tersebut. Regulasi ini tidak mengatur mengenai program TJSL, namun hanya sekedar meminta pelaku usaha untuk turut melaksanakan program pengembangan dan pemberdayaan masyarakat setempat. ${ }^{24}$ Secara umum kegiatan tersebut dapat diwujudkan melalui penyebaran informasi dan manfaat dari kegiatan pengusahaan panas bumi tersebut kepada masyarakat setempat. Masyarakat juga berhak mendapat ganti rugi yang layak akibat kesalahan dalam kegiatan pengusahaan panas bumi. ${ }^{25}$

\section{Undang-Undang Nomor 32 Tahun 2009 tentang Perlindungan dan Pengelolaan Lingkungan Hidup}

Walaupun Undang-Undang Lingkungan Hidup tidak pernah secara khusus menggunakan suatu istilah untuk menyebutkan kewajiban TJSL, namun perlindungan dan pengelolaan lingkungan hidup dapat dimengerti sebagai suatu upaya sistematis dan terpadu untuk melestarikan fungsi lingkungan dan mencegah terjadinya pencemaran dan kerusakan lingkungan hidup. ${ }^{26}$ Subjek dan kewajiban kegiatan TJSL diketahui dari Pasal 68 yang menyatakan bahwa setiap orang memiliki kewajiban salah satunya untuk menjaga keberlanjutan fungsi lingkungan hidup.

Selain tidak mengatur mengenai sumber dana maupun alokasinya, peraturan ini juga tidak mengatur kegiatan dan program TJSL secara spesifik. Namun pelaksanaan kegiatan TJSL dapat berdasarkan prinsip-prinsip untuk meningkatkan kepedulian dalam perlindungan dan pengelolaan lingkungan hidup, meningkatkan kemandirian, keberdayaan masyarakat serta kemitraan,

\footnotetext{
${ }^{23}$ Ibid., Pasal 1.

${ }^{24}$ Ibid., Pasal 52.

${ }^{25}$ Ibid., Pasal 65 ayat (2).

26 Pasal 1 ayat (2) Undang-Undang Nomor 32 Tahun 2009 tentang Perlindungan dan Pengelolaan Lingkungan Hidup.
} 
menumbuhkan kemampuan dan kepeloporan masyarakat, menumbuhkan ketanggapan masyarakat dalam melakukan pengawasan sosial, serta mengembangkan dan menjaga budaya serta kearifan lokal dalam rangka pelestarian fungsi lingkungan hidup. ${ }^{27}$ Pembangunan keberlajutan tersebut dapat diwujudkan melalui usaha terencana untuk memadukan aspek lingkungan hidup, sosial, dan ekonomi ke dalam strategi pembangunan agar tidak hanya menjamin keutuhan lingkungan hidup namun juga keselamatan, kemampuan, kesejahteraan, dan mutu generasi masa kini dan generasi yang akan datang. ${ }^{28}$

\section{Undang-Undang Nomor 19 Tahun 2003 tentang Badan Usaha Milik Negara}

Pasal 3 Undang-Undang Badan Usaha Milik Negara (UU BUMN) menyebutkan bahwa salah satu tujuan pendirian BUMN adalah untuk turut aktif memberikan bantuan dan bimbingan kepada pengusaha golongan ekonomi lemah, koperasi, dan masyarakat, yang disebut sebagai program kemitraan. Tentu saja yang menjadi subjek atas kewajiban ini adalah yang dikategorikan sebagai BUMN baik Perusahaan Umum, Perusahaan Persero, maupun Persero Terbuka.

Menurut Pasal 88, BUMN dapat menyisihkan sebagian laba bersihnya untuk keperluan pembinaan usaha kecil dan pembinaan masyarakat tersebut. Namun besaran dana yang harus dialokasikan belum diatur dalam regulasi ini. Secara khusus dan lebih rinci, besaran dana dan program yang diharapkan diatur dalam Peraturan Menteri Badan Usaha Milik Negara Nomor PER-02/MBU/7/2017 tentang Perubahan Kedua atas Peraturan Menteri Badan Usaha Milik Negara Nomor PER-09/MBU/07/2015 tentang Program Kemitraan dan Program Bina Lingkungan Badan Usaha Milik Negara.

Peraturan Menteri Badan Usaha Milik Negara Nomor PER-02/MBU/7/2017 tentang Program Kemitraan dan Program Bina Lingkungan Badan Usaha Milik Negara

Peraturan Menteri BUMN No. PER-02/MBU/7/2017 sebagai derivasi dari Undang-Undang Nomor 19 Tahun 2003 tentang Badan Usaha Milik Negara berusaha mengelaborasi lebih lanjut mengenai konsep TJSL yang wajib dilaksanakan oleh BUMN melalui program kemitraan dan program bina lingkungan. Regulasi ini

27 Ibid., Pasal 70.

${ }^{28}$ Ibid., Pasal 1 ayat (3). 
mengatur secara detail mengenai bentuk-bentuk program serta alokasi dan sumber dana yang diperlukan untuk pelaksanaan program-program ini. Program Kemitraan merupakan program untuk meningkatkan kemampuan usaha kecil agar menjadi lebih mandiri melalui bantuan dana dari BUMN. Sedangkan Program Bina Lingkungan merupakan program untuk memperbaiki kondisi sosial masyarakat yang ditetapkan dan dilaksanakan oleh BUMN di wilayah usaha BUMN yang bersangkutan. BUMN berbentuk Perum dan Persero wajib melaksanakan Program Kemitraan dan Bina Lingkungan (PKBL) sesuai dengan ketentuan Peraturan Menteri sedangkan Persero Terbuka dapat melaksanakan PKBL sesuai dengan ketetapan Rapat Umum Pemegang Saham atau RUPS.

Dana untuk Program Kemitraan dan Program Bina Lingkungan bersumber dari penyisihan maksimum $4 \%$ dari proyeksi laba bersih BUMN tahun sebelumnya dan/atau anggaran yang diperhitungkan sebagai biaya BUMN. Angka ini secara pasti ditetapkan oleh Menteri untuk Perum, oleh RUPS bagi Persero, dan oleh Dewan Komisaris untuk Persero terbuka. Dana juga dapat berasal dari saldo dana program tahun sebelumnya, hasil bunga deposito maupun jasa giro, dan pelimpahan dana dari BUMN lain, jika ada. Dalam hal BUMN tidak memperoleh laba, maka besaran anggaran PKBL paling banyak sebesar dana tahun sebelumnya.

Usaha yang berhak mengikuti Program Kemitraan harus memenuhi syaratsyarat tertentu. Apabila disetujui untuk diberikan bantuan, maka mitra harus membayar kembali pinjaman secara tepat waktu sesuai dengan perjanjian serta menyampaikan laporan perkembangan usaha secara periodik kepada BUMN Pembina. ${ }^{29}$ Kerja sama tersebut dituangkan dalam perjanjian kerja sama yang sekurang-kurangnya memuat maksud dan tujuan kerja sama, jumlah dana, hak dan kewajiban masing-masing pihak, jangka waktu kerja sama, sanksi, keadaan memaksa, dan penyelesaian perselisihan. Dana dari Program Kemitraan dapat disalurkan dalam bentuk pinjaman untuk membiayai modal kerja atau pembelian aset, sebagai pinjaman tambahan untuk membiayai kebutuhan yang bersifat jangka pendek dalam rangka memenuhi pesanan dari rekanan usaha Mitra, maupun diwujudkan dalam bentuk pendidikan, pelatihan, pemagangan, pemasaran,

\footnotetext{
${ }^{29}$ Pasal 4 Peraturan Menteri BUMN No. PER-02/MBU/7/2017 tentang Program Kemitraan dan Program Bina Lingkungan
} 
promosi, dan edukasi lain yang menyangkut peningkatan produktivitas Mitra maksimal sebesar 20\% dari total dana Program Kemitraan yang disalurkan pada tahun berjalan. Dana yang diberikan untuk setiap Mitra adalah maksimal sebesar Rp. $200.000 .000,00.30$

Menurut regulasi ini, Program Bina Lingkungan yang dapat dilakukan oleh suatu BUMN mencakup bantuan korban bencana alam, bantuan pendidikan berupa pelatihan, sarana, dan prasarana, bantuan peningkatan kesehatan, bantuan pengembangan sarana dan prasarana umum, bantuan sarana ibadah, bantuan pelestarian alam, bantuan sosial kemasyarakatan untuk pengentasan kemiskinan seperti elektrifikasi daerah yang belum dialiri listrik, penyediaan sarana air bersih, penyediaan sarana Mandi Cuci Kakus, perbaikan rumah untuk masyarakat tidak mampu, bantuan pembibitan untuk pertanian, peternakan, dan perikanan, bantuan peralatan usaha, hingga bantuan-bantuan lain dalam upaya peningkatan kemandirian ekonomi usaha kecil selain Mitra binaannya.

Berbagai peraturan yang mengandung norma TJSL, ditemukan bahwa tidak semua peraturan telah menggunakan frasa yang konsisten. Istilah "Tanggung Jawab Sosial dan Lingkungan" dapat dikenal juga dengan istilah "Program Kemitraan dan Bina Lingkungan," "pemberdayaan masyarakat," hingga "pelestarian lingkungan." Perbedaan istilah ini sedikit banyak menimbulkan kesalahan penafsiran sehingga penerapannya pun tidak dapat diharapkan sama. Sebagai contoh adalah penafsiran menurut Kementerian Lingkungan Hidup yang menyebutkan bahwa TJSL, CSR, maupun pemberdayaan masyarakat adalah 3 konsep yang berbeda. Pemberdayaan masyarakat didefinisikan sebagai suatu proses untuk menciptakan kemajuan kondisi ekonomi dan sosial melalui partisipasi aktif sehingga dapat menimbulkan kemandirian dalam masyarakat. Konsep CSR dipandang sebagai konsep yang memayungi kegiatan pemberdayaan masyarakat dan TJSL, sedangkan TJSL menurut UUPT dinilai sebagai kewajiban yang berasal dari undang-undang. Ketidakkonsistenan ini dapat terjadi karena belum ada konsep dan ruang lingkup yang jelas mengenai TJSL itu sendiri.

${ }^{30}$ Ibid., Pasal 9. 
Penggunaan frasa, subjek, sumber dana, alokasi, dan program TJSL diterjemahkan dalam peraturan-peraturan yang mengandung konsep CSR dapat dirangkum sebagai berikut:

\begin{tabular}{|c|c|c|c|c|c|c|}
\hline No. & Peraturan & Frasa & Subjek & $\begin{array}{c}\text { Sumber } \\
\text { Dana }\end{array}$ & Alokasi & Program \\
\hline 1. & $\begin{array}{l}\text { Undang- } \\
\text { Undang Nomor } \\
40 \text { tahun } 2007 \\
\text { tentang } \\
\text { Perseroan } \\
\text { Terbatas }\end{array}$ & $\begin{array}{l}\text { Tanggung } \\
\text { Jawab Sosial } \\
\text { dan } \\
\text { Lingkungan }\end{array}$ & $\begin{array}{l}\text { Perseroan } \\
\text { Terbatas } \\
\text { bidang } \\
\text { SDA }\end{array}$ & $\begin{array}{l}\text { Biaya } \\
\text { perseroan }\end{array}$ & $\begin{array}{l}\text { Sesusai } \\
\text { RUPS } \\
\text { dengan } \\
\text { memperha } \\
\text { tikan } \\
\text { kepatutan } \\
\text { dan } \\
\text { kewajaran }\end{array}$ & $\begin{array}{l}\text { Tidak } \\
\text { diatur }\end{array}$ \\
\hline 2. & $\begin{array}{l}\text { Undang- } \\
\text { Undang Nomor } \\
25 \text { Tahun } 2007 \\
\text { tentang } \\
\text { Penanaman } \\
\text { Modal }\end{array}$ & $\begin{array}{l}\text { Tanggung } \\
\text { jawab sosial } \\
\text { Perusahaan }\end{array}$ & $\begin{array}{l}\text { Penanam } \\
\text { modal }\end{array}$ & $\begin{array}{l}\text { Biaya } \\
\text { perseroan }\end{array}$ & $\begin{array}{l}\text { Tidak } \\
\text { diatur }\end{array}$ & $\begin{array}{l}\text { Tidak } \\
\text { diatur }\end{array}$ \\
\hline 3. & $\begin{array}{l}\text { Undang- } \\
\text { Undang Nomor } \\
22 \text { Tahun } 2001 \\
\text { tentang Minyak } \\
\text { dan Gas Bumi }\end{array}$ & $\begin{array}{l}\text { Pengelolaan } \\
\text { lingkungan } \\
\text { hidup, } \\
\text { pengembang } \\
\text { an } \\
\text { masyarakat } \\
\text { sekitar, } \\
\text { jaminan hak } \\
\text { masyarakat }\end{array}$ & $\begin{array}{l}\text { Pemegang } \\
\text { Izin Usaha }\end{array}$ & $\begin{array}{l}\text { Tidak } \\
\text { diatur }\end{array}$ & $\begin{array}{l}\text { Tidak } \\
\text { diatur }\end{array}$ & $\begin{array}{l}\text { Tidak } \\
\text { diatur }\end{array}$ \\
\hline 4. & $\begin{array}{l}\text { Undang- } \\
\text { Undang Nomor } \\
4 \text { Tahun } 2009 \\
\text { tentang } \\
\text { Pertambangan } \\
\text { Mineral dan } \\
\text { Batubara }\end{array}$ & $\begin{array}{l}\text { Pengembang } \\
\text { an dan } \\
\text { pemberdayaa } \\
\text { n manusia }\end{array}$ & $\begin{array}{l}\text { Pemegang } \\
\text { Izin Usaha } \\
\text { Pertamban } \\
\text { gan dan } \\
\text { Izin Usaha } \\
\text { Pertamban } \\
\text { gan } \\
\text { Khusus }\end{array}$ & $\begin{array}{l}\text { Biaya } \\
\text { program } \\
\text { pengemba } \\
\text { ngan dan } \\
\text { masyaraka } \\
\text { t yang } \\
\text { dianggark } \\
\text { an dalam } \\
\text { Rencana } \\
\text { Kerja }\end{array}$ & $\begin{array}{l}\text { Tidak } \\
\text { diatur }\end{array}$ & $\begin{array}{l}\text { Tidak } \\
\text { diatur }\end{array}$ \\
\hline 5. & $\begin{array}{l}\text { Undang- } \\
\text { Undang Nomor } \\
21 \text { Tahun } 2014 \\
\text { tentang Panas } \\
\text { Bumi }\end{array}$ & $\begin{array}{l}\text { Pengembang } \\
\text { an dan } \\
\text { pemberdayaa } \\
\text { n masyarakat } \\
\text { setempat }\end{array}$ & $\begin{array}{l}\text { Pemegang } \\
\text { izin }\end{array}$ & $\begin{array}{l}\text { Tidak } \\
\text { diatur }\end{array}$ & $\begin{array}{l}\text { Tidak } \\
\text { diatur }\end{array}$ & $\begin{array}{l}\text { Tidak } \\
\text { diatur }\end{array}$ \\
\hline
\end{tabular}




\begin{tabular}{|c|c|c|c|c|c|c|}
\hline 6. & $\begin{array}{l}\text { Undang- } \\
\text { Undang Nomor } \\
32 \text { Tahun } 2009 \\
\text { tentang } \\
\text { Perlindungan } \\
\text { dan } \\
\text { Pengelolaan } \\
\text { Lingkungan } \\
\text { Hidup }\end{array}$ & $\begin{array}{l}\text { Menjaga } \\
\text { keberlanjutan } \\
\text { fungsi } \\
\text { lingkungan } \\
\text { hidup }\end{array}$ & $\begin{array}{l}\text { Semua } \\
\text { pelaku } \\
\text { usaha }\end{array}$ & $\begin{array}{l}\text { Tidak } \\
\text { diatur }\end{array}$ & $\begin{array}{l}\text { Tidak } \\
\text { diatur }\end{array}$ & $\begin{array}{l}\text { Tidak } \\
\text { diatur }\end{array}$ \\
\hline 7. & $\begin{array}{l}\text { Undang- } \\
\text { Undang Nomor } \\
19 \text { Tahun } 2003 \\
\text { tentang Badan } \\
\text { Usaha Milik } \\
\text { Negara }\end{array}$ & $\begin{array}{l}\text { Bantuan dan } \\
\text { bimbingan } \\
\text { kepada } \\
\text { pengusaha } \\
\text { golongan } \\
\text { ekonomi } \\
\text { lemah }\end{array}$ & BUMN & $\begin{array}{l}\text { Laba } \\
\text { bersih }\end{array}$ & $\begin{array}{l}\text { Tidak } \\
\text { diatur }\end{array}$ & $\begin{array}{l}\text { Progra } \\
\text { m } \\
\text { kemitra } \\
\text { an }\end{array}$ \\
\hline 8. & $\begin{array}{l}\text { Peraturan } \\
\text { Menteri Badan } \\
\text { Usaha Milik } \\
\text { Negara Nomor } \\
\text { PER- } \\
\text { 02/MBU/7/201 } \\
7 \text { tentang } \\
\text { Program } \\
\text { Kemitraan dan } \\
\text { Program Bina } \\
\text { Lingkungan } \\
\text { Badan Usaha } \\
\text { Milik Negara }\end{array}$ & $\begin{array}{l}\text { Program } \\
\text { Kemitraan } \\
\text { dan Program } \\
\text { Bina } \\
\text { Lingkungan }\end{array}$ & BUMN & $\begin{array}{l}\text { Laba } \\
\text { bersih } \\
\text { dan/atau } \\
\text { anggaran } \\
\text { diperhitun } \\
\text { gkan } \\
\text { sebagai } \\
\text { biaya }\end{array}$ & $\begin{array}{l}\text { Maksimu } \\
\text { m } 4 \% \text { dari } \\
\text { proyeksi } \\
\text { laba bersih } \\
\text { tahun } \\
\text { sebelumny } \\
\text { a }\end{array}$ & $\begin{array}{l}\text { Progra } \\
\mathrm{m} \\
\text { kemitra } \\
\text { an, } \\
\text { progra } \\
\mathrm{m} \text { bina } \\
\text { lingkun } \\
\text { gan }\end{array}$ \\
\hline
\end{tabular}

Subjek yang wajib melaksanakan konsep CSR juga beragam. UUPT Undanghanya membatasi kegiatan TJSL untuk Perseroan Terbatas yang bergerak di sektor sumber daya alam, namun peraturan lain meminta perusahaan perorangan atau wiraswasta untuk turut melaksanakannya. Walaupun beberapa undang-undang sektoral seperti lingkungan hidup, kehutanan, minyak dan gas bumi, serta mineral dan batu bara telah mengatur mengenai siapa yang memiliki kewajiban TJSL, namun masalah multitafsir muncul dari frasa "mengelola dan memanfaatkan sumber daya alam" atau "berdampak pada fungsi kemampuan sumber daya alam" pada Pasal 74 UUPT. Secara sederhana, kalimat ini hanya mengacu kepada perusahaan-perusahaan pertambangan atau yang mengelola sumber daya alam 
secara langsung. Namun UUPM justru menginstruksikan bahwa TJSL wajib dilaksanakan bagi setiap penanam modal, di mana seluruh perseroan terbatas merupakan subjeknya. Sehingga muncul inkonsistensi mengenai siapa saja yang menjadi subjek dari kewajiban TJSL ini.

Tumpang tindih peraturan ini berpotensi menimbulkan konflik manakala sebuah BUMN yang juga merupakan Peseroan bergerak di bidang sumber daya alam. Atas bentuk perusahaan tersebut maka akan muncul pertanyaan apakah Badan Usaha Milik Negara tersebut hanya tunduk kepada Undang-Undang Badan Usaha Milik Negara dan Peraturan Menteri Badan Usaha Milik Negara karena peraturan bersifat lex specialis atau juga tunduk pada Undang-Undang Perseroan Terbatas karena Badan Usaha Milik Negara juga dapat berbentuk perseroan. Konsekuensinya, timbul keraguan apakah Program Kemitraan dan Program Bina Lingkungan yang dilakukan oleh BUMN sudah dianggap cukup untuk memenuhi ketentuan TJSL pada Undang-Undang PT.

Program Kemitraan sendiri merupakan program untuk meningkatkan kemampuan usaha kecil agar lebih tangguh dan mandiri melalui bantuan kredit atau dana, sedangkan Program Bina Lingkungan merupakan program pemberdayaan kondisi sosial masyarakat dan lingkungan. Apabila dilihat dari dampak atau manfaat yang dihasilkan, akan nampak bahwa ada kesamaan antara PKBL dengan TJSL. Kedua konsep ini sama-sama bertujuan untuk peningkatan kesejahteraan dan pemberdayaan komunitas di area sekitar operasional perusahaan. Namun apabila dilihat dari sisi pemerataan manfaatnya, keduanya memiliki target persebaran yang berbeda. Ekspektasi persebaran manfaat Tanggung Jawab Sosial dan Lingkungan hanya terbatas di komunitas atau lingkungan tempat perseroan berada atau menjalankan kegiatan operasionalnya, sedangkan lokasi PKBL dapat mencakup seluruh wilayah Indonesia dan tidak terbatas hanya pada domisili BUMN saja.

Apabila dilihat dari sisi pendanaannya, PKBL tidak dapat dikategorikan sebagai bentuk kegiatan TJSL seperti amanat Undang-Undang PT. Karena UndangUndang tersebut menginstruksikan kewajiban TJSL perseroan dianggarkan dan diperhitungkan sebagai biaya Perseroan dengan memperhatikan kepatutan dan kewajaran, sedangkan Undang-Undang BUMN menyebutkan bahwa pelaksanaan 
PKBL berasal dari penyisihan laba maksimal sebesar 2\% untuk masing-masing program. Perbedaan ini mengesankan bahwa PKBL tidak dapat berjalan bagi BUMN yang tidak berhasil memperoleh laba sedangkan kegiatan TJSL harus tetap berjalan karena telah dianggarkan sebelumnya. Tumpang tindih produk hukum ini memiliki konsekuensi bagi BUMN yang bergerak di bidang sumber daya alam dengan pertanyaan apakah BUMN ini dikenai 2 kewajiban yang substansi dan tujuannya kurang lebih sama, yaitu pemerataan manfaat terutama sumber daya alam. ${ }^{31}$

Inkonsistensi lain dapat dilihat dari sisi sanksi. Peraturan Menteri BUMN tidak mengatur perihal sanksi bagi BUMN yang tidak melaksanakan PKBL, di mana Pasal 30 ayat (1) hanya sekedar menggunakan pelaksanaan PKBL sebagai salah satu indikator penilaian kesehatan BUMN. Sedangkan Pasal 74 ayat (3) Undang-Undang Perseroan Terbatas juga hanya mengatakan bahwa akan dikenai sanksi sesuai ketentuan perundang-undangan tanpa menyebutkan secara konkret. Sedangkan bentuk sanksi menurut UUPM adalah peringatan tertulis, pembatasan kegiatan usaha, hingga pembekuan dan pencabutan kegiatan usaha atau fasilitas penanaman modal. ${ }^{32}$ Sanksi-sanksi tersebut cenderung lemah dan dapat dengan mudah dipandang sebelah mata oleh pelaku bisnis, sehingga harapan atas pelaksanaan TJSL yang optimum tidak akan dapat tercapai.

Selain sanksi untuk organisasi-organisasi itu sendiri, sanksi yang diberikan kepada penerima bantuan juga dianggap lemah dan tidak mendidik. Hal ini perlu menjadi perhatian, terutama sanksi untuk mitra Program Kemitraan sesuai dengan Peraturan Menteri BUMN mengenai PKBL. Dalam peraturan itu disebutkan bahwa sanksi atas kegagalan pembayaran kewajiban pokok dan/atau bunga sehingga mengakibatkan kualitas pinjaman menjadi macet adalah penghapusan dalam catatan BUMN saja. Tidak ada panduan mengenai langkah represif yang perlu dilakukan untuk mengembalikan pinjaman yang telah diberikan kepada mitra.

Berdasarkan fakta hukum tersebut, maka berbagai peraturan terkait TJSL masih multitafsir dan tidak dapat membentuk suatu sistem hukum yang dapat

\footnotetext{
31 Muhammad Rutabuz Zaman, 2016, “Tinjauan Hukum Terhadap Tanggung Jawab Sosial Perusahaan (Istilah, Konsep, Ruang Lingkup Serta Implikasi Hukumnya)," Miyah XI (01), hlm. 97.

32 Pasal 34 Undang-Undang Nomor 25 Tahun 2007 tentang Penanaman Modal
} 
mewujudkan pemerataan manfaat. Atas dasar itu, maka perlu dibuat satu peraturan yang komprehensif yang paling sedikit memiliki pembahasan yang jelas mengenai:

Pertama penggunaan frasa harus mencerminkan suatu model yang berorientasi jangka panjang dan berguna bagi masyarakat. Frasa "Program Kemitraan" dan "Program Bina Lingkungan" sesuai Peraturan Menteri BUMN dapat dinilai mengesankan tujuan tersebut, sehingga dapat dipilih untuk diadopsi dalam model yang baru. Secara psikologis, kata "kemitraan" atau kerja memberikan efek terbuka dan kekeluargaan sehingga tidak menimbulkan kesan atasan dan bawahan. Sedangkan kata "bina" mengesankan suatu usaha untuk memperbaiki dan mendampingi, sehingga ada tendensi untuk peningkatan kualitas, tidak hanya sekedar memperbaiki sesuatu yang telah rusak. Kedua, subjek kegiatan TJSL perlu mencakup semua kalangan di bidang usaha walaupun kontribusi setiap pihak tidak harus sama. Seperti pepatah "sedikit demi sedikit lama-lama menjadi bukit", apabila setiap pihak berkontribusi maka manfaat yang terkumpul akan besar juga.

Ketiga, program kemitraan dapat dikonstruksikan pinjaman kepada pengusaha UMKM yang telah berjalan minimum 1 tahun. Hal ini berarti pengusaha memang memiliki komitmen dan diharapkan telah memiliki jaringan yang cukup. Keempat, jangka waktu pinjaman dapat ditentukan melalui analisis IDIR (Installment to Disposible Income Ratio) harus lebih kecil dari 100\%. Kelima, skema pembayaran kembali dapat berupa angsuran tetap (pokok dan bunga) mapun angsuran bertahap (bunga secara bulanan, pokok di akhir jangka waktu) yang perlu disesuaikan dengan tipe usahanya.

Keenam, program Bina Lingkungan yang dapat dilakukan untuk TJSL yang berorientasi pengembangan yang berkelanjutan, seperti pembangunan perbaikan sarana prasarana pendidikan, kesehatan, sanitasi dan air bersih, lahan usaha, elektrifikasi daerah terpencil, beasiswa dan pendampingan usaha lainnya. Ketujuh, dana sebaiknya bersumber dari penyisihan laba perusahaan. Karena tujuan utama suatu usaha adalah pencapaian profit sebesar-besarnya, maka munculnya biaya yang tidak berkontribusi langsung dengan peningkatan pendapatan biasanya akan diminimalkan. Untuk menghindari efek tersebut, maka lebih menguntungkan bagi 
masyarakat apabila pembagian manfaat didasarkan pada peroleh laba, yang berusaha dicapai sebesar-besarnya oleh perusahaan.

Kedepalan, pemberian bantuan harus dalam porsi yang secukupnya dan dibagikan ke beberapa daerah yang berbeda. Hal ini perlu dilakukan untuk menghindari ketergantungan masyarakat terhadap bantuan. Apabila diberikan secara terus menerus, secara psikologis manusia akan menjadi malas dan berpikiran bahwa tanpa melakukan apapun bantuan tetap datang. Ketika cara berpikir semacam ini mulai muncul maka kegiatan TJSL tidak lagi efektif dan alihalih mencapai tujuan pemerataan, kegiatan TJSL berpotensi menimbulkan masalah sosial baru berupa kemalasan dan ketergantungan.

\section{Penutup}

Istilah, konsep, ruang lingkup dan mekanisme penerapan Tanggung Jawab Sosial dan Lingkungan (TJSL) dalam berbagai peraturan perundang-undangan belum konsisten. Hal ini berasal dari banyaknya istilah yang digunakan untuk menyebut kewajiban TJSL dalam berbagai peraturan. Istilah yang berbeda dapat memunculkan penafsiran yang berbeda sehingga dapat diartikan sebagai hal yang berbeda. Pengaturan juga dinilai tidak konsisten karena perbedaan ketentuan antara peraturan satu dengan yang lain. Berdasarkan teori Fuller, maka peraturanperaturan yang multitafsir ini tidak dapat berfungsi untuk mencapai tujuan utamanya. Sehingga, inkonsistensi dalam pengaturan TJSL di Indonesia akan mengakibatkan tujuan pemerataan sumber daya alam tidak tercapai. Pengaturan TJSL yang baik perlu memperhatikan tujuan dari TJSL itu sendiri dan mengkombinasikannya dengan asas keadilan sosial dan ketuhanan yang dianut oleh bangsa Indonesia melalui Pancasila. Konsep TJSL tidak hanya perlu dikualitatifkan dengan angka atau persentase yang direkomendasikan, namun juga perlu memberikan referensi kegiatan-kegiatan pemberdayaan yang sebaiknya dilakukan.

\section{Daftar Pustaka}

\section{Buku}

Elkington, John, Cannibals with Forks: The Triple Bottom Line of 21st Century Business, Capstone, Minnesota, 1999. 
Mardikanto, Totok, CSR (Corporate Social Responsibility) (Tanggungjawab Sosial Korporasi), Alfabeta, Bandung, 2014.

Schumacher, E. F., Small is Beautiful: Economics As If People Mattered, Harper \& Row, New York, 1973.

Soemarwoto, Otto, Dampak Lingkungan dan Masyarakat, Gadjah Mada University Press, Yogyakarta, 2000.

Zafer, M. R., Jurisprudence: An Outline, International Law Book Series, Kuala Lumpur, 1994.

\section{Jurnal}

Adinugroho, Samuel R., Budiharto, Joko Priyono, “Pelaksanaan tanggung jawab sosial dan lingkungan PT. Pertamina Semarang (Persero) ditinjau dari Undang-Undang Nomor 40 Tahun 2007 tentang Perseroan Terbatas", Diponegoro Law Journal Vol. 6 No. 1, 2007.

DesJardins, Joseph, "Corporate Environmental Responsibility," Journal of Business Ethics Vol. 17 No. 8, 1998.

Mohr, Lois A., Deborah, J. Webb dan Katherine E. Harris, “Do Consumers Expect Companies to be Socially Responsible? The Impacts of Corporate Social Responsibility on Buying Behavior", Journal of Consumer Affairs Vol. 35 No. 1, 2001.

Murphy, Colleen, "Lon Fuller and the Moral Value of the Rule of Law", Law and Philosophy Vol. 24, 2005.

Ireland, Paddy, "Limited Liability, Shareholder Rights and the Problem of Corporate Irresponsibility," Cambridge Journal of Economics Vol. 34 No. 5, 2010.

Perkins, Douglas D. dan Marc A. Zimmerman, “Empowerment Theory, Research, and Application," American Journal of Community Psychology 23(5), 1995.

Waagstein, Patricia Rinwigati, “The Mandatory Corporate Social Responsibility in Indonesia: Problems and Implications", Journal of Business Ethics Vol. 98, 2010.

\section{Peraturan Perundang-Undangan}

Undang-Undang Dasar Negara Republik Indonesia Tahun 1945.

Undang-Undang Nomor 22 Tahun 2001 tentang Minyak dan Gas Bumi, Lembaran Negara Republik Indonesia Tahun 2001 Nomor 136.

Undang-Undang Nomor 19 Tahun 2003 tentang Badan Usaha Milik Negara, Lembaran Negara Republik Indonesia Tahun 2003, Tambahan Lembaran Negara RI Nomor 4297.

Undang-Undang Nomor 25 Tahun 2007 tentang Penanaman Modal, Lembaran Negara Republik Indonesia Tahun 2007, Tambahan Lembaran Negara RI Nomor 4724. 
Undang-Undang Nomor 40 Tahun 2007 tentang Perseroan Terbatas, Lembaran Negara Republik Indonesia Tahun 2007, Tambahan Lembaran Negara RI Nomor 4756.

Undang-Undang Nomor 4 Tahun 2009 tentang Pertambangan Mineral dan Batubara, Lembaran Negara Republik Indonesia Tahun 2009, Tambahan Lembaran Negara RI Nomor 4959.

Undang-Undang Nomor 32 Tahun 2009 tentang Perlindungan dan Pengelolaan Lingkungan Hidup, Lembaran Negara Republik Indonesia Tahun 2009, Tambahan Lembaran Negara RI Nomor 5059.

Peraturan Pemerintah Nomor 47 Tahun 2012 tentang Tanggung Jawab Lingkungan dan Sosial Perseroan Terbatas, Lembaran Negara Republik Indonesia Tahun 2012, Tambahan Lembaran Negara RI Nomor 5305.

Peraturan Menteri Badan Usaha Milik Negara Nomor PER-02/MBU/07/2017 tentang Perubahan Kedua Atas Peraturan Menteri Badan Usaha Milik Negara Nomor PER-09/MBU/07/2015 tentang Program Kemitraan dan Program Bina Lingkungan Badan Usaha Milik Negara, Berita Negara Republik Indonesia Tahun 2017 Nomor 1002. 